\title{
Reflection on Telemedicine Competencies in Spanish Medicine Degrees After the COVID-19 Pandemic
}

\author{
Julian Alberto GARCIA-GARCIA a , Nicolas SANCHEZ-GÓMEZ ${ }^{\text {a }}$, \\ Cristina RAMÍREZ DE VERGER ${ }^{\text {a, }}{ }^{\text {, Maria Jose BAUTISTA-LLAMAS }}{ }^{\mathrm{a}}$ and \\ Jose NAVARRO-PANDO ${ }^{\mathrm{a}, \mathrm{b}}$ \\ ${ }^{a}$ IWT2 Research Group, University of Seville \\ ${ }^{\mathrm{b}}$ Inebir INC, Seville
}

\begin{abstract}
The pandemic suffered in 2020 following the appearance of the SARSCoV-2 virus has marked a radical change in the way in which the basic pillars of international, and more specifically Spanish, society are understood. The existing social and economic model has had to adapt abruptly and urgently to the reality of what has happened. The impact that these changes will have after the pandemic is still unclear, but it may be surmised that many of them are here to stay. The use of information and communication technologies has been critical in the pandemic scenario and also in the health environment, where factors like telemedicine have come to play a key role for society. This work presents an initial analysis of how degrees in Medicine train students for telematic work with patients and provides a series of reflections based on the pandemic which may serve as a point of departure for future studies.
\end{abstract}

Keywords. Computer Science, Telemedicine, ICT Doctor Competencies

\section{Introduction}

The pandemic experienced worldwide in 2020 due to SARS-CoV-2 has caused society to make radical changes in all walks of life. The principles that regulate our social and work life have had to adapt quickly and abruptly to a new situation [17]. In this change, information and communication technologies (ICTs) have been crucial. Indeed, it has been possible to continue much socio-economic activity thanks to the use of videoconferences, telematic mechanisms and technological solutions that have alleviated the impact of the pandemic, at least to the extent allowed by the situation [3]. Although it is early to accurately predict how the lessons learned in this stage will affect social and professional relationships, we can now surmise that some of the changes that have taken place will have opened up lines of work which will undoubtedly play a fundamental role in the near future [4]. Health workers have been one of the groups, if not the group, most affected by the pandemic. We are referring not only to those specialists who have fought directly against SARS-CoV-2, but also to professionals with other specializations who have been forced to adapt their procedures to the situation. The use made of telemedicine in areas such as psychology or pediatrics during lockdown is therefore worthy of

\footnotetext{
${ }^{1}$ Corresponding Author, Cristina Ramirez de Verger cristina.ramirez@iwt2.org
} 
attention. Telemedicine is not a new practice. In fact, it had already been offered by different companies and organizations even before COVID-19 and for years the ICT sector has been working hand in hand with the health sector on its use [9]. During the pandemic and lockdown, however, the process of its use and implementation had to be accelerated. Training to conduct telemedicine does not only require technical knowledge of the tools to be used [18]. Medical experts must be aware of the possibilities ICTs open up in this regard, but also of the limitations involved. It is also necessary to incorporate competencies into their training syllabuses so that in the future they may be able to perform this type of health work in an appropriate manner [8]. In this paper, we will begin by analyzing how current regulations support telematics training for doctors. We will take as an example two currently offered degrees, one in a public university and the other in a private university, and look at how telemedicine standards are instantiated in each. This will help us engage with those aspects which need to be incorporated and improved. The paper is structured as follows: Section 2 presents an overview of the current situation and regulations; Section 3 describes the method used to choose which degrees to analyze and provides an overview of how each syllabus implements the training required by the regulations. Finally, there are some conclusions and suggestions for future work that may derive from our analysis.

\section{Background}

The objectives or competencies that Medicine graduates must attain are structured in seven blocks: (A) Professional values, attitudes and ethical behavior, (B) Scientific grounding in medicine, (C) Clinical skills, (D) Communication skills, (E) Public health and health systems, (F) Information management, and (G) Critical analysis and research. In turn, there are 37 specific competencies that detail each of these categories or blocks. Given that work in telemedicine is related to communication skills, we will look at the competencies related to block D and, more specifically, at those oriented towards favoring doctor-patient communication. These competencies, numbers 23 and 24, are as follows:

- 23. Communicate effectively and clearly, both orally and in writing, with patients, family members, the media and other professionals.

- 24. Establish good interpersonal communication that enables patients, family members, the media, and other professionals to speak efficiently and with empathy.

After analyzing the competencies, the standard goes on to address aspects related to the Planning of Teaching. Here, in the module dedicated to Social Medicine, Communication Skills and Initiation of Research, there is a specific reference to the need for medical professionals to "know the principles of telemedicine", although no further details are given about the extent to which a graduate in Medicine must be able to diagnose illness, monitor patients, or even prescribe medication using telemedicine.

This suggests that although the regulatory framework of reference includes telemedicine and offers the channels to guarantee doctor-patient communication, it is in the instantiation of the standard that we have to look for the mechanism with which to implement it. 


\section{Method}

In this section, we will take two degrees as examples with which to carry out a preliminary analysis of the situation. We start by justifying our choice of degree courses and describing the method of analysis to be used.

\subsection{Degree selection}

The Registry of Universities, Colleges and Qualifications [15] of Spain's Ministry of Science, Innovation and Universities currently lists 42 organizations offering degrees in Medicine in Spain. To specify our initial analysis, and to have two different references in two different settings, we will take a degree from a private university and one from a public university. Choosing from all the possible options in the national education system is a complex task, and a comprehensive study of all the courses available is outside the scope of this work. Our first search therefore focused on trying to find the best-valued degrees in Medicine according to different rankings [2] [6] [7]. We were subsequently able to deduce that although no such specific ranking exists, Medicine syllabuses at most universities and colleges are broadly similar. From the faculties listed, we finally selected the first public one and the first private one that appear in the Shanghai ranking [16], opting to analyze the degrees in Medicine from the University of Barcelona [12] and the University of Navarra [13], respectively.

\subsection{Method of study}

Analysis of the degree courses focused on how both competencies and teaching planning are implemented in each, analyzing those competencies closely related to telemedicine [11], as presented in the Background section. To do this, it was necessary to review the degrees, starting with official study plans and then also looking at modifications to the syllabuses in question. The RUCT (Spanish Registry of Universities, Centers and Titles) repository was used as a source of information, together with the universities' web pages and the public information they offer about their courses. As mentioned in Section 2, two specific aspects of how the standard is implemented were analyzed, namely:

1. How competencies 23 and 24 are achieved and whether any aspects of IT for doctorpatient communication are included in the training plans.

2. How the aspect of "Knowing the principles of Telemedicine" is implemented within the module dedicated to Social Medicine, Communication Skills and Initiation of Research.

3. For each degree, we also analyzed if the degree includes any complementary training or optional courses related to telemedicine.

\section{Results}

This section shows the results of instantiating the method presented in the previous section. Specifically, this section presents the cases of the University of Barcelona and the University of Navarra.

On the one hand, the Degree in Medicine at the University of Barcelona was approved in 2008 by the National Agency for Quality Assessment and Accreditation 
(hereinafter ANECA), in accordance with Article 25 of Royal Decree 1393/2007. It was possible to analyze the situation using information from the academic year 2019/2020, available on the University website. Analyzing the strategic points established for this degree, we obtained the information shown in Table 1.

Table 1. Analysis of the methodology used in the Degree in Medicine at the University of Barcelona

\begin{tabular}{|c|c|}
\hline Competence 23 & $\begin{array}{l}\text { This is instantiated in specific and transverse competencies: } \\
\text { - CE50. To communicate in a clear, effective way, both orally and in writing, with } \\
\text { patients, family and accompanying persons to facilitate decision making, informed } \\
\text { consent, and the course of medical treatment. } \\
\text { - CT8. To communicate in a clear and effective way, both orally and in writing, with } \\
\text { other professionals and media. }\end{array}$ \\
\hline Competency 24 & $\begin{array}{l}\text { This is instantiated in a specific competency in the degree: } \\
\text { - CE48. To establish good interpersonal communications, to talk efficiently and } \\
\text { empathetically with patients, family, accompanying persons, doctors and other health } \\
\text { professionals. }\end{array}$ \\
\hline $\begin{array}{l}\text { "Knowledge of } \\
\text { the basic } \\
\text { principles of } \\
\text { telemedicine" }\end{array}$ & $\begin{array}{l}\text { This aspect is included as a sub-section (1.4) in specific competency } 1 \text { (CE1. } \\
\text { Recognizing the essential elements of the medical profession as a result of an } \\
\text { evolutionary scientific, socio-cultural process. Including ethical principles, legal } \\
\text { responsibilities and patient-centered professional practices.). It is covered } \\
\text { comprehensively in a basic, generic subject. }\end{array}$ \\
\hline Other subjects & $\begin{array}{l}\text { The degree course offers two optional subjects related to telemedicine or ICT: } \\
\text { - Subject } 364514 \text {. Patient-Centered Medicine } \\
\text { - Subject } 364381 \text {. Introduction to ICT in Health. }\end{array}$ \\
\hline
\end{tabular}

On the other hand, the degree in Medicine at the University of Navarra [13] was accredited by ANECA in 2008. It subsequently underwent several modifications, the last being in 2018. As was expected, the available information showed that the University of Navarra has instantiated all aspects of the standard. Table 2 shows how this has been done.

Table 2. Analysis of the methodology used in the Degree in Medicine at the University of Navarra

\begin{tabular}{|l|l|}
\hline Competency 23 & $\begin{array}{l}\text { This is instantiated in a global competency identified using the same name-CG23- } \\
\text { in the degree. }\end{array}$ \\
\hline Competency 24 & $\begin{array}{l}\text { This is instantiated in a global competency identified using the same name-CG24- } \\
\text { in the degree. }\end{array}$ \\
\hline $\begin{array}{l}\text { "Knowledge of } \\
\text { the basic } \\
\text { principles of } \\
\text { telemedicine" }\end{array}$ & $\begin{array}{l}\text { The basic principles of telemedicine are included in the degree as a specific } \\
\text { competency: CE61, Knowledge of the basic principles of telemedicine. }\end{array}$ \\
\hline
\end{tabular}

\section{Discussion}

The previous section presents preliminary reflections after analyzing two Medicine degrees. In these Medicine degrees, telemedicine training is rarely presented. At this point, two questions can be asked. The first is whether it is really necessary to provide special training to allow doctors to be able to exercise their profession using telemedicine. The answer is yes, and that is precisely what is stated in the regulatory standard governing the profession. The second question is what doctors really need to be trained in, and it is here that the problem arises. The COVID-19 pandemic has shown that the technology is there, and that telemedicine is possible, at least in a significant number of specializations [4]. But it has also shown that the training required to be able to conduct telemedicine goes beyond familiarity with technological tools. Doctors must know how 
to communicate, empathize, and make themselves understood through telemedicine in the same way that they do with patients in face-to-face consultations [1]. Our brief reflection is intended to show that this is not currently the case.

\section{Conclusions}

During the pandemic, the technologies have been in place and ready to support telemedicine, but in many cases hospitals and clinics have been unable to implement it due to lack of resources and training. This paper presents an initial reflection on Telemedicine Competencies in Spanish Medicine Degrees after the COVID-19 Pandemic. On the other hand, the regulations governing degrees in Medicine in Spain do offer an adequate frame of reference in support of this need. It can therefore be deduced that what is needed is more reflection on the specific competencies that medicine graduates need to acquire in order to treat patients via telemedicine [10]. Those competencies must cover not only the technical aspects but also the management, health and communication skills that will ensure the correct execution of the medical profession just as it is practiced in the consulting room or the hospital environment [18]. The COVID-19 pandemic has shown that telemedicine is necessary and, to some extent, has accelerated the process of its implementation. It should be noted that the changes that must take place are not limited to medicine. Other environments, such as nursing, must also be taken into account since, as has been shown, they too are necessary when addressing the new challenges facing our society.

Finally, it is important to mention that this article presents initial reflections, but, as future work, we plan to extend this analysis to more universities and higher medical studies.

\section{Acknowledgment}

This research is partially supported by NICO (Nuevas Iniciativas para el Aseguramiento Temprano de la Calidad Funcional y no Funcional en Procesos y Productos Software Orientados al Usuario) (PID2019-105455GB-C31), which is funded by Spanish Ministry of Science, Innovation and Universities; and TRoPA (Early Testing in Medical Robotics Process Automation) (CEI-12), which is funded by Andalusian Regional Ministry of Economy, Knowledge, Business and University.

\section{References}

[1] Agha Z, Schapira RM, Laud PW, McNutt G, Roter DL. Patient satisfaction with physician-patient communication during telemedicine. Telemed J E Health. 2009 Nov;15(9):830-9. doi: 10.1089/ tmj.2009.0030.

[2] BBVA 2020. U-Ranking, Available at https://www.u-ranking.es/analisis.php, Accessed April, 2020.

[3] ComputerWorld. Especial Coronavirus. Tecnología frente a la Pandemia. Nº1376. Año XXXVII. Abril 2020. Available at https://www.computerworld.es/pubs/COVID-19/, Accessed April 2020.

[4] Deloitte 2020. El impacto económico del COVID 19, Available at https:/www2.deloitte.com/es/es/ pages/about-deloitte/articles/impacto-economico-del-covid19.html. Accessed April, 2020.

[5] EEEE 2020, Available at http://www.eees.es/, Accessed April, 2020.

[6] El Español 2020, Available at https://www.elespanol.com/ciencia/investigacion/20181003/mejoresfacultades-estudiar-medicina-espana/342467117_0.htm, Accessed April 2020. 
[7] El Mundo. Available at https://www.elmundo.es/especiales/ranking-universidades/index.html. Accessed April, 2020.

[8] Gustke S, Balch S, Rogers LO. Patient satisfaction telemedicine. Telemedicine Journal. 2000;6(1), 5-13.

[9] Judi H, Razak AA, Sha'ari N, Mohamed H. Feasibility and critical success factors in implementing telemedicine. Information Technology Journal. 2009;8(3), 326-332.

[10] McConnochie KM, Conners GP, Brayer AF, Goepp J, Herendeen NE, Wood NE, Thomas A, Ahn DS, Roghmann KJ. Differences in diagnosis and treatment using telemedicine versus in-person evaluation of acute illness. Ambul Pediatr. 2006 Jul-Aug;6(4):187-95; discussion 196-7.

[11] Picot J. Meeting the need for educational standards in the practice of telemedicine and telehealth. J Telemed Telecare. 2000;6 Suppl 2:S59-62.

[12] UBA 2020. Grado en Medicina. Universitat de Barcelona, Available at https://www.ub.edu/portal/web/medicina-ciencies-salut/verificacio-seguiment-modificacio-i-acreditacio

[13] UNA 2020. Grado en Medicina. Universidad de Navarra, Available at https:/www.unav.edu/web/gradoen-medicina/inicio

[14] Master en telemedicina, Avilable at https://www.uoc.edu/portal/es/qualitat/qualitat-titulacions/ avaluacio-titulacions/ciencies-salut/mu-telemedicina-ext/index.html

[15] RUCT 2020, Avilable at https://www.educacion.gob.es/ruct/home, Accessed April, 2020.

[16] Ranking de Shanghai, Avilable at http://www.shanghairanking.com/arwu2019.html, Accessed April, 2020.

[17] World Health Organization. 2020. Coronavirus disease 2019 (COVID-19): situation report, 67.

[18] Zayapragassarazan Z, Kumar S. Awareness, Knowledge, Attitude and Skills of Telemedicine among Health Professional Faculty Working in Teaching Hospitals. J Clin Diagn Res. 2016 Mar;10(3):JC01-4. 